\title{
Valorization of rice husk ash in ceramic bricks
}

\section{(Valorização de cinza de casca de arroz em tijolos)}

\author{
P. Milak ${ }^{1}$, M. T. Souza ${ }^{1,2 *}$, C. P. Bom ${ }^{1}$, P. Mantas ${ }^{1}$, F. Raupp-Pereira ${ }^{2}$, A. P. Novaes de Oliveira ${ }^{2}$ \\ ${ }^{1}$ Department of Ceramic and Glass, University of Aveiro, Portugal \\ ${ }^{2}$ Department of Mechanical Engineering, Federal University of Santa Catarina, Florianópolis, Brazil \\ *engmarcelosouza@hotmail.com
}

\begin{abstract}
Thermal comfort of residential buildings has become an important factor for the performance and functional application of materials in constructive systems. In this scenario, it also takes some concepts related to sustainability, such as the recycling of industrial wastes. Many of these materials, such as rice husk ash (RHA), become interesting mineral alternatives for production of structural and/or sealing ceramics blocks with insulating properties. In this paper, ceramic samples of formulated compositions constituted of natural raw materials (clays) and rice husk ash (8 to $20 \mathrm{wt} \%)$ as an alternative mineral source, were appropriated prepared, extruded and then, after drying process at $110^{\circ} \mathrm{C}$, fired at $965{ }^{\circ} \mathrm{C}$ for $2 \mathrm{~h}$. The results showed the feasibility of adding rice husk ash in the production of ceramic blocks with porosities in the 16 to $32 \%$ range, resulting in a considerable reduction of their thermal conductivities (up to $27 \%$ ).
\end{abstract}

Keywords: rice husk ash, lightweight ceramic, thermal conductivity.

\section{Resumo}

O conforto térmico em edifícios residenciais tornou-se um fator importante para o desempenho e aplicação funcional de materiais em sistemas construtivos. Neste cenário, adota-se também alguns conceitos relacionados à sustentabilidade, como a reciclagem de resíduos industriais. Muitos destes materiais, como a cinza de casca de arroz, tornam-se alternativas minerais interessantes para a produção de blocos de cerâmica estrutural elou de vedação com propriedades isolantes. Neste trabalho, amostras cerâmicas de composições formuladas constituídas de matérias-primas naturais (argilas) e cinza de casca de arroz (8 a 20\% em massa), como fonte mineral alternativa, foram preparadas, extrudadas e na sequência, após processo de secagem a $110{ }^{\circ} \mathrm{C}$, queimadas a $965{ }^{\circ} \mathrm{C}$ durante 2 h. Os resultados mostraram a viabilidade da adição de cinza de casca de arroz na produção de blocos cerâmicos com porosidades entre 16 e 32\%, resultando em considerável redução de sua condutividade térmica (até 27\%).

Palavras-chave: cinza de casca de arroz, cerâmica leve, condutividade térmica.

\section{INTRODUCTION}

Rice is the cereal most produced over the world. In Brazil, according to data from the National Supply Company, the production of paddy rice for the harvest in 2013/2014 was estimated in 12.2 million tons [1]. In fact, Brazil's agricultural production is very strong and, as a result of this activity, large quantities of agricultural and agro-industrial wastes are produced. About $23 \mathrm{wt} \%$ of the rice grain is composed by husk [2], which is separated in the processing of rice. Traditionally, rice husk $(\mathrm{RH})$ has been considered a waste material and generally disposed by dumping or burning [3], since it is a low-density material with high calorific power $(\sim 16 \mathrm{MJ} / \mathrm{kg})$, and is therefore widely used as a fuel for drying and for parboiling of the cereal itself [4, 5]. However, the heat recovery process from RH generates a new waste, the rice husk ash (RHA). Around $3.5 \mathrm{wt} \%$ of the total estimated production of rice correspond to the ash. The RHA in turn contains around $85 \%$ to $90 \%$ amorphous silica [6], which is an important raw material used in the ceramic industry and an interesting mineral alternative for production of structural and/or sealing ceramics blocks with insulating properties.

Considering the evolution of the environmental laws related to the activities of mining and production of building materials, the use of alternative raw materials has become an important sustainable choice for reducing consumption of natural resources. Recent researches report the use of RHA in many applications, like partial replacement for cement in concrete [7-9], in whiteware compositions [10, 11], as quartz substitute for the production of ceramic glaze [12], and glass-ceramic tiles [13]. The objective of this paper was to valorize the rice husk ash for the production of ceramic materials with better thermal insulation properties.

\section{EXPERIMENTAL}

In this work, rice husk ash (RHA) and two natural raw materials, named yellow clay and red clay, were used for the preparation of the formulated ceramic materials. A commercial formulation containing chamotte (fired ceramics from broken products) was also used as reference 
material (RM). Five compositions constituted by the clays and different RHA contents $(0,8,12,16$ and $20 \mathrm{wt} \%)$ were prepared (Table I). To investigate the crystalline nature of used raw materials, powdered samples were analyzed with a Philips PW 3710 X-ray $(\mathrm{CuK} \alpha)$ diffractometer (XRD). The volatile percentage of the RHA was determined by simultaneous thermogravimetric and differential thermal analysis (TGA/DTA, TA Instruments, SDT Q600) at a heating rate of $10^{\circ} \mathrm{C} / \mathrm{min}$ and oxidizing atmosphere.

Table I - Formulated compositions. RM: reference; RHA: rice husk ash.

[Tabela I - Composições formuladas. RM: referência; RHA: cinza de casca de arroz.]

\begin{tabular}{ccccc}
\hline Sample & Yellow clay & Red clay & Chamotte & RHA \\
\hline RM & 42 & 42 & 16 & - \\
P0 & 50 & 50 & - & - \\
P8 & 46 & 46 & - & 8 \\
P12 & 44 & 44 & - & 12 \\
P16 & 42 & 42 & - & 16 \\
P20 & 40 & 40 & - & 20 \\
\hline
\end{tabular}

After drying $\left(110^{\circ} \mathrm{C} / 24 \mathrm{~h}\right)$, compositions were crushed (Servitech, CT-058) and milled for $30 \mathrm{~min}$ in a fast mill (Servitech, CT-242) constituted by a porcelain jar containing alumina balls, RHA and water (28\%), so that powders with particle sizes lower than $44 \mu \mathrm{m}$ were obtained. The moist powders were extruded (Netzsch extruder MA 01), obtaining cylindrical samples with nominal dimensions of $160 \mathrm{~mm}$ (length) and $12 \mathrm{~mm}$ (diameter). The produced ceramic bodies were naturally dried at room temperature for 5 days and then dried at $110{ }^{\circ} \mathrm{C}$ in a laboratory dryer up to constant weight. After drying, the powder compacts were fired in a muffle kiln at $965^{\circ} \mathrm{C}$ for $2 \mathrm{~h}$, with heating rate of $10^{\circ} \mathrm{C} / \mathrm{min}$. This firing temperature was chosen since it is typically used in industrial production of this type of materials.

The fired samples were characterized by bending strength $\left(\sigma_{\mathrm{f}}\right)$ and water absorption (WA), according to the ISO 10545-3 standard [14]. The bending strength was performed in a test machine (Emic, DL 2000) according to ISO 10545-4 [15], which consisted in a three-point test on six samples with dimensions of $100 \mathrm{~mm}$ x $50 \mathrm{~mm}$ $\mathrm{x} 10 \mathrm{~mm}$ at a stress rate of $1 \mathrm{MPa} \cdot \mathrm{s}^{-1}$. The true densities $\left(Q_{t}\right)$ of powdered samples were determined using a helium pycnometer (Micromeritics, AccuPyc 1340). The apparent densities $\left(\mathrm{Q}_{\mathrm{a}}\right)$ of fired samples were determined by relating their geometrical measurements, obtained using a caliper (Mitotoyo, accuracy $\pm 0.01 \mathrm{~mm}$ ), and their weights (balance Shimadzu AX200 with a precision of $0.001 \mathrm{~g})$. From measurements of geometrical $\left(\mathrm{Q}_{\mathrm{a}}\right)$ and true $\left(\mathrm{Q}_{\mathrm{t}}\right)$ densities, the porosities $(\varepsilon)$ of the ceramics were calculated according to:

$$
\varepsilon(\%)=\left(1-\frac{\rho_{\mathrm{a}}}{\rho_{\mathrm{t}}}\right) \cdot 100
$$

The thermal conductivity of the obtained materials was measured on samples with nominal dimensions of $80 \mathrm{~mm}$ in length and $24 \mathrm{~mm}$ in diameter in the range of 30 to 70 ${ }^{\circ} \mathrm{C}$ by using a Transmission de Chaleur ET100 - Deltalab. The equipment provided the heat transfer $(\mathrm{Q})$ through the samples by:

$$
\mathrm{Q}=\frac{\mathrm{ht}}{\mathrm{ct}} \cdot \mathrm{U} \cdot \mathrm{I}
$$

where the ht is the heating time (s), ct is the cycle time (s), U is the voltage (V) and I the current (A). The thermal conductivity (k) was obtained using the Fourier law, according to:

$$
\mathrm{k}=\frac{\mathrm{Q} \cdot \mathrm{t}}{\mathrm{A} \cdot \Delta \mathrm{T}}
$$

where $\mathrm{t}$ is the thickness of the sample, $\mathrm{A}$ is the area and $\Delta \mathrm{T}$ is the differential temperature. The data obtained of each composition was expressed in percentage in relation to the reference material $(\mathrm{k}=0.92 \mathrm{~W} / \mathrm{mK})$.

\section{RESULTS AND DISCUSSION}

Fig. 1 shows X-ray diffraction patterns relative to the yellow and red clays and RHA. In both clays, peaks characteristics of quartz, $\mathrm{S}: \mathrm{SiO}_{2}$ (JCPDS 05-0490), were identified, among those of kaolinite, $\mathrm{K}: \mathrm{Al}_{2} \mathrm{Si}_{2} \mathrm{O}_{5}(\mathrm{OH})_{4}$ (JCPDS 29-1488), and muscovite, $\mathrm{M}: \mathrm{X}_{2} \mathrm{Y}_{4-6} \mathrm{Z}_{8} \mathrm{O}_{20}(\mathrm{OH}, \mathrm{F})_{4}$ (JCPDS 02-055), a phyllosilicate of the micas group, whose chemical composition consists essentially of: $\mathrm{X}=$ $\mathrm{K}, \mathrm{Na}, \mathrm{Ca} ; \mathrm{Y}=\mathrm{Al}, \mathrm{Mg}$ or $\mathrm{Fe}$, and $\mathrm{Z}=\mathrm{Si}$ or $\mathrm{Al}$. It was also detected in the red clay, the presence of montmorillonite, MM: (Mg,Ca)O. $\mathrm{Al}_{2} \mathrm{O}_{3} \mathrm{Si}_{5} \mathrm{O}_{10} \cdot \mathrm{nH}_{2} \mathrm{O}$ (JCPDS 07-0304), thus indicating greater water retention capacity and possibly greater plasticity. In the RHA, it was observed a structure

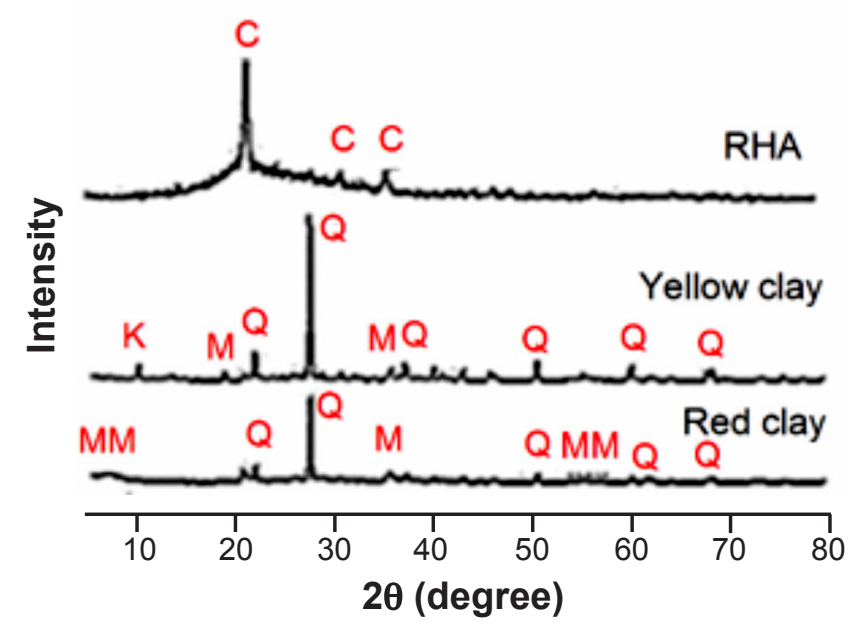

Figure 1: X-ray diffraction patterns of the RHA, yellow clay and red clay. C: cristobalite; K: kaolinite; M: muscovite; Q: quartz; MM: montmorillonite.

[Figura 1: Difratogramas de raios $X$ da cinza (RHA), argila amarela e argila vermelha. C: cristobalita; $K$ : caulinita; $M$ : muscovita; Q: quartzo; MM: montmorilonita.] 
partially amorphous (elevation in the baseline in the $2 \theta$ range between 15 and $40^{\circ}$ ) and partially crystalline. The peaks at 22,32 and $36^{\circ}$ correspond to cristobalite, $\mathrm{C}: \mathrm{SiO}_{2}$ (JCPDS 89-3435). The firing temperature of the rice husk can promote changes on the structure of the RHA, in which, from $800{ }^{\circ} \mathrm{C}$, the previously amorphous material begins to form crystalline phases, as shown in Fig. 1 [13, 16, 17].

Fig. 2 shows the DTA/TGA curves of the RHA. Two thermal events were observed in the DTA/TGA curves. The first $\left(\mathrm{E}_{1}\right)$ is an endothermic event related to humidity evaporation with a weight loss of $4.6 \%$ up to $100{ }^{\circ} \mathrm{C}$. The second $\left(\mathrm{E}_{2}\right)$ is an exothermic event related to the RHA crystallization (mainly cristobalite, see Fig. 1), which begins at around $820{ }^{\circ} \mathrm{C}$ and peaking at $1070{ }^{\circ} \mathrm{C}$. The TGA curve also showed that at $965^{\circ} \mathrm{C}$ (firing temperature of specimens) the weight loss reached $6.5 \%$.

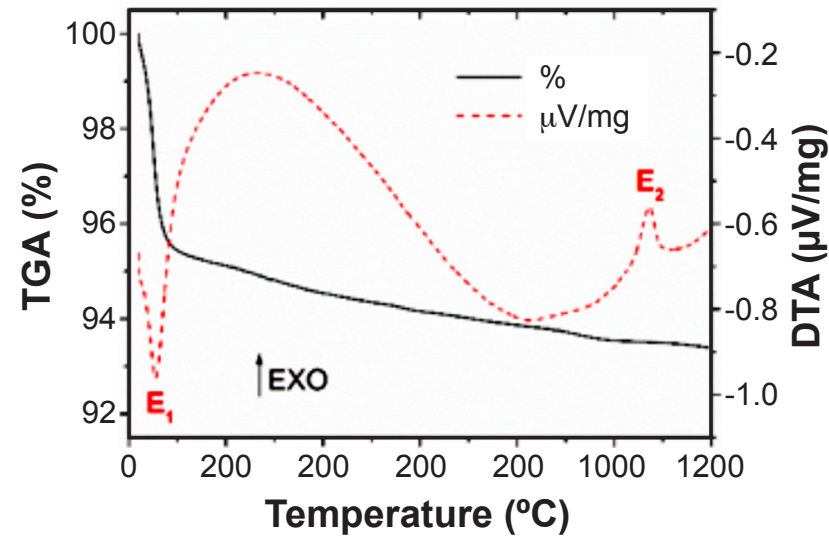

Figure 2: TGA/DTA curves of RHA.

[Figura 2: Curvas de DTA/TGA da cinza (RHA).]

Fig. 3 shows the results of porosity $(\varepsilon)$, bending strength $\left(\sigma_{\mathrm{f}}\right)$ and water absorption (WA) for the different studied compositions. The addition of RHA increased the porosity, i.e. 16\% (for composition RM and P0) to 32\% (for composition P20). Comparing compositions RM and $\mathrm{P} 0$, it was observed that the use of chamotte (RM) did not cause

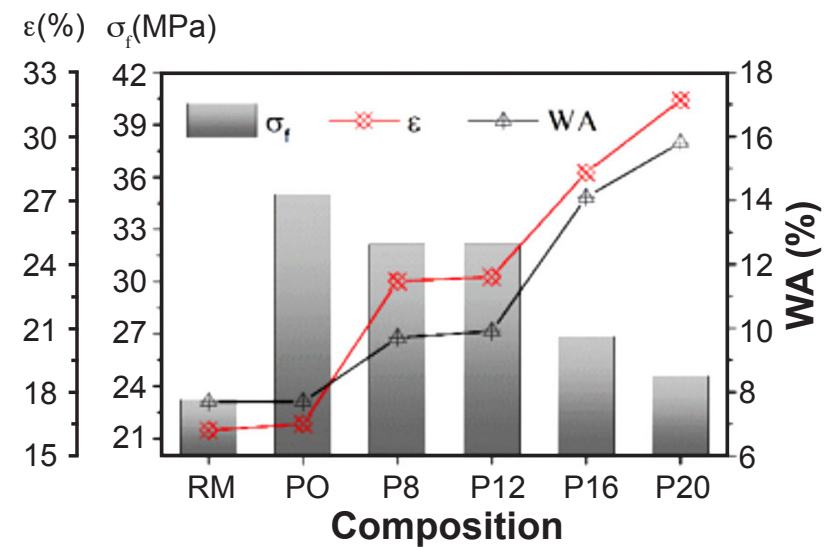

Figure 3: Porosity $(\varepsilon)$, bending strength $\left(\sigma_{f}\right)$ and water absorption (WA) of the studied compositions.

[Figura 3: Porosidade (ع), resistência à flexão $\left(\sigma_{\mathrm{f}}\right)$ e absorção de água (WA) das composições estudadas.]

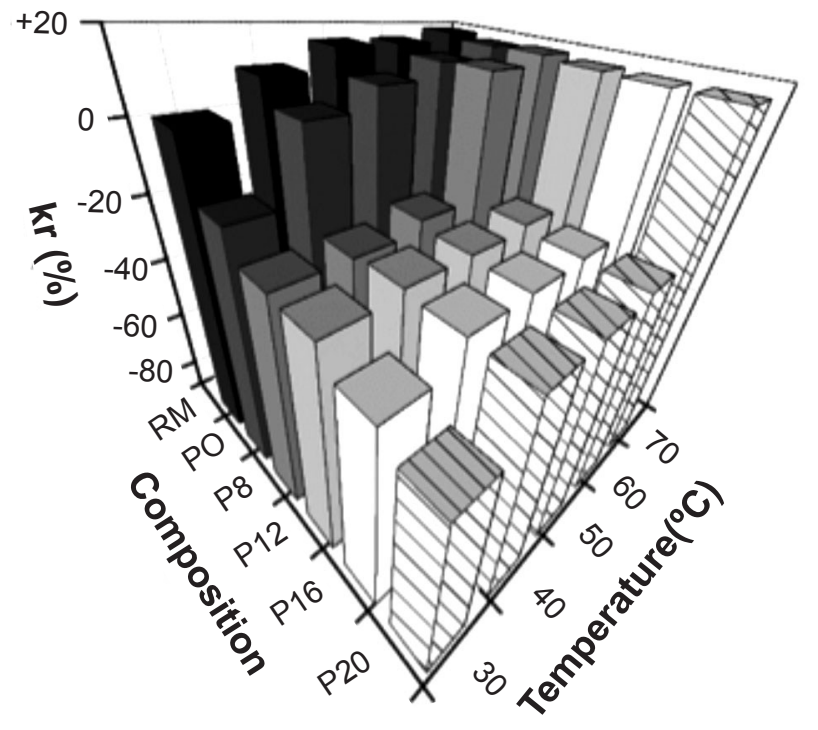

Figure 4: Relative thermal conductivity $(\mathrm{kr})$ of the studied compositions as a function of temperature.

[Figura 4: Condutividade térmica relativa $(\mathrm{kr})$ das composições estudadas em função da temperatura.]

large change in porosity; however, the bending strength was considerably lower ( $\sim 23 \mathrm{MPa})$ compared to composition P0 ( $\sim 35 \mathrm{MPa})$. The RHA addition promoted an increase in porosity and, consequently, an increase in water absorption, resulting in lightweight ceramic bodies with values of bending strength similar to that of the RM.

The "pore" phase plays a key role in improving the material insulating characteristic by air trapping, whose thermal conductivity is very low $\left(\mathrm{k}_{\mathrm{ar}}=0.026 \mathrm{~W} / \mathrm{mK}\right)$. Thus, as can be seen in the Fig. 4, the incremental additions of RHA promoted a formation of pores by the evaporation of the volatile portion (mainly residual carbon) $[18,19]$ and, consequently, a reduction in thermal conductivity. The thermal conductivity (k) depends on the intrinsic properties of the related materials and/or of the constitutive phases of the materials. The amorphous phase, introduced by RHA, also justifies the reduction in thermal conductivity observed in the studied compositions [17]. It was observed that the relative thermal conductivity of all compositions increased with increasing temperature. Therefore, the improvement of the insulating properties of the studied compositions (except composition P8) is conditioned to temperatures up to $60{ }^{\circ} \mathrm{C}$.

\section{CONCLUSIONS}

The results showed the feasibility of using RHA up to $12 \mathrm{wt} \%$, with a low reduction $(\sim 10 \%)$ of the bending strength and a great reduction of the thermal conductivity (k), i.e., comparing $\mathrm{P} 0$ and $\mathrm{P} 12, \mathrm{k}$ decreased $20 \%$ at $30^{\circ} \mathrm{C}$ and $30 \%$ at $60^{\circ} \mathrm{C}$.

\section{REFERENCES}

[1] Nat. Supply Co. (CONAB), Monitoring of the Brazilian 
grain harvest 2012/13.

[2] V.P. Della, I. Kühn, D. Hotza, Mater. Lett. 57, 4 (2002) 818.

[3] G.A. Habeeb, M.M. Fayyadh, Aust. J. Basic Appl. Sci. 3, 3 (2009) 1616.

[4] S.D. Nagrale, H. Hajare, P.R. Modak, Int. J. Eng. Res. Applic. 2, 4 (2012) 1.

[5] R.V. Krishnarao, J. Subrahmanyam, T.J. Kumar, J. Eur. Ceram. Soc. 21 (2001) 99.

[6] R. Hamid, N. Ibrahim, A. Jamadin, Int. J. Eng. Sci. 2, 2 (2013) 50.

[7] A.N. Givi, S.A. Rashid, F.N.A. Aziz, M.A.M. Salleh, J. Am. Sci. 6, 3 (2010) 157.

[8] M. Alhassan, A.M. Mustapha, Leonardo El. J. Pract. Technol. 11 (2007) 47.

[9] I.O. Obilade, Int. J. Eng. Appl. Sci. 5, 4 (2014) 11.

[10] C.S. Prasada, K.N. Maitib, R. Venugopalc, Ceram. Int. 27, 6 (2001) 629.

[11] C.S. Prasada, K.N. Maitib, R. Venugopalc, Ceram. Int. 29, 8 (2003) 907.
[12] F. Bondioli, L. Barbieri, A.M. Ferrari, T. Manfredini, J. Am. Ceram. Soc. 93, 1 (2009) 121.

[13] F. Andreola, M.I. Martín, A.M. Ferrari, I. Lancellotti, F. Bondioli, J.Ma. Rincón, M. Romero, L. Barbieri, Ceram. Int. 39, 5 (2013) 5427.

[14] ISO 10545-3, "Ceramic tiles - determination of water absorption, apparent porosity, apparent relative density and bulk density", $2^{\text {nd }}$ ed. (2004).

[15] ISO 10545-4, "Ceramic tiles - determination of modulus of rupture and breaking strength", $2^{\text {nd }}$ ed. (2004).

[16] F. Bondioli, L. Barbieri, F. Andreola, M. Bonvicini, Brick World Rev. 1 (2010) 34.

[17] M.A. Hamad, L.A. Khattab, Thermochem. Acta 48, 3 (1981) 343.

[18] S.D. Genieva, S.C. Turmanova, A.S. Dimitrova, L.T. Vlaev, J. Therm. Anal. Calorim. 93, 2 (2008) 387.

[19] A.S. Grove, Physics and technology of semiconductor devices, John Wiley \& Sons, New York (1967).

(Rec. 01/08/2016, Rev. 23/09/2016, 28/11/2016, 22/12/2016, Ac. 21/02/2017) 